\title{
Major Miocene geological events in southern Tibet and eastern Asia induced by the subduction of the Ninetyeast Ridge
}

\author{
Xinlei Sun ${ }^{1}$ Wei-dong Sun Su, $^{2,3,4}$ Yong-bin $\mathrm{Hu}^{5,6} \cdot$ Wei Ding ${ }^{5}$ Trevor Ireland ${ }^{7}$. \\ Mei-zhen Zhan ${ }^{1} \cdot$ Ji-qiang Liu ${ }^{5} \cdot$ Ming-xing Ling ${ }^{1} \cdot$ Xing Ding $^{1} \cdot$ Zhao-feng Zhang $^{1}$ • \\ Wei-ming Fan $^{4}$
}

Received: 14 November 2017/Revised: 2 January 2018/Accepted: 30 January 2018/Published online: 16 February 2018

(C) Science Press, Institute of Geochemistry, CAS and Springer-Verlag GmbH Germany, part of Springer Nature 2018

\begin{abstract}
Cenozoic adakitic rocks in the Gangdese changed from barren continental melts to ore-forming slab melts at $\sim 23 \mathrm{Ma}$. The distribution and chemical characteristics of the ore-forming adakites point to an association with the Ninetyeast Ridge. The subduction of the thick, rigid Ninetyeast Ridge changed the geometry and rheology of the eastern Tibetan Plateau lithosphere and asthenosphere, restrained the eastward escape of asthenospheric mantle as well as continental fragments, and promoted the uplift and building of the Tibetan Plateau, which consequently changed the tectonic and climatic regimes in eastern Asia.
\end{abstract}

Wei-dong Sun

weidongsun@gig.ac.cn

1 State Key Laboratory of Isotope Geochemistry, Guangzhou Institute of Geochemistry, Chinese Academy of Sciences, Guangzhou 510640, China

2 Center of Deep Sea Research, Institute of Oceanography, Chinese Academy of Sciences, Qingdao 266071, China

3 Laboratory for Marine Mineral Resources, Qingdao National Laboratory for Marine Science and Technology, Qingdao 266237, China

4 CAS Center for Excellence in Tibetan Plateau Earth Sciences, Chinese Academy of Sciences, Beijing 100101, China

5 CAS Key Laboratory of Mineralogy and Metallogeny, Guangzhou Institute of Geochemistry, Chinese Academy of Sciences, Guangzhou 510640, China

6 University of the Chinese Academy of Sciences, Beijing 100049, China

7 Research School of Earth Sciences, The Australian National University, Canberra, ACT 2601, Australia
Keywords Ridge subduction - Eastern Tibetan Plateau . Cenozoic mineralization $\cdot$ Seismic anomaly

\section{Introduction}

The interaction between the Indian and Eurasian plates is an ongoing example of continent-continent collision and continental subduction, the details of which are of critical importance to better understand the formation of the Himalaya and Tibetan Plateau, and plate tectonics in general.

The Tibetan Plateau is the highest and largest orogenic belt on Earth's surface, standing $\sim 5000 \mathrm{~m}$ above sea level with an area of $\sim 3$ million $\mathrm{km}^{2}$. It appears to have mainly formed through crustal shortening and thickening after collision of the Indian and Eurasian continents commenced at $\sim 34$ to $55 \mathrm{Ma}$ (Tapponnier et al. 2001; Aitchison et al. 2007; Royden et al. 2008; Meng et al. 2012; Ding et al. 2017). In contrast to the dramatic crustal shortening in western and central Tibet immediately following the collision, eastern Tibet is characterized by the escape of large fragments of lithosphere that started at 40-35 Ma (Tapponnier et al. 2001; Royden et al. 2008). Meanwhile, major geologic events occurred around the Tibetan Plateau: southward extrusion of the Indochina Peninsula (Tapponnier et al. 1982), large-scale dextral movement of the Red River-Ailaoshan shear zone (Leloup et al. 1995), rapid trench retreat along much of the west Pacific, Philippine, and Indonesian oceanic subduction boundaries as indicated by widespread Early Cenozoic extension (Hall and Morley 2004), Eocene-Oligocene extension in the South and East China Seas (Taylor and Hayes 1980; Sibuet et al. 2004), and formation of other extensional basins along the continental margins of Asia 
(Maruyama et al. 2009). These have been attributed to geometric accommodation associated with oblique collision/subduction (Tapponnier et al. 2001) and partially to trench retreat in the western Pacific and Indonesian arcs (Royden et al. 2008).

Major tectonic changes occurred in the Miocene. The tectonic regime of the Tibetan Plateau changed to rapid uplift and crustal thickening in southern Tibet $\sim 20 \mathrm{Ma}$ (Harrison et al. 1992) and the Plateau likely reached its current height at $\sim 15 \mathrm{Ma}$ (Spicer et al. 2003), initiating the present-day Asian monsoons (Licht et al. 2014). The escape of lithospheric fragments to the east of the Plateau and trench retreats along the eastern margin of Eurasia appear to stop at about the same time, implying close connections between these events (Royden et al. 2008). Meanwhile, Cenozoic porphyry copper mineralization has been documented in the Gangdese belt, southern Tibet (Hou et al. 2009; Xiao et al. 2012). The geochemistry of these porphyry deposits provides clues to the mechanism that controlled/coordinated these major collision-associated tectonic events. Here we show that all these events were associated with the subduction of the Ninetyeast Ridge.

\section{Results}

The Gangdese porphyry-copper-deposit belt is the largest of its type in China, being $\sim 400 \mathrm{~km}$ in length and $\sim 100 \mathrm{~km}$ in width. It is in the southeastern Tibetan Plateau, next to the eastern Himalayan syntaxis (Figs. 1 and 2). Adakitic porphyries associated with ores formed at 23-15 Ma (Hou et al. 2009; Xiao et al. 2012), about 10-35 Ma younger than the collision between the Indian and Eurasian continents (Aitchison et al. 2007; Meng et al. 2012). Based mainly on these ages, the deposits were assumed to be typical post-collisional orogenic copper porphyries (Hou et al. 2009). Consequently, the formation of these ore-forming adakites was attributed to partial melting of underplated mafic lower crust or relicts of previously subducted oceanic slabs induced either by slab breakoff or mantle thinning in an extensional setting (Hou et al. 2004, 2009, 2015).

Geochemically, post-collisional ore deposits are usually sulfur-poor and gold-rich (Richards 2009). In contrast, the Gangdese porphyries are sulfur-rich and gold-poor, and are associated with highly oxidized adakite with abundant magnetite-hematite and anhydrite ( $\mathrm{Hu}$ et al. 2015; Sun et al. 2015). For example, the Qulong porphyry, the largest copper deposit in China, has anhydrite contents ranging from $5 \mathrm{vol} \%$ to $90 \mathrm{vol} \%$ in veins, and $1 \mathrm{vol} \%$ to $5 \mathrm{vol} \%$ in altered rocks (Xiao et al. 2012). Such high sulfur contents are seen mostly in arc environments, not in post-collisional settings (Richards 2009).

Remarkably, there was a major transition in the geochemistry of the adakites in the Gangdese at $\sim 23 \mathrm{Ma}$. Adakite was originally defined as being associated with partial melting of subducted oceanic slabs, with close spatial relationship with young $(<25 \mathrm{Ma})$, hot subducting oceanic plates (Defant and Drummond 1990). Later studies have suggested that some adakitic rocks may have formed through partial melting of thickened/delaminated lower continental crust (Chung et al. 2003; Gao et al. 2004; Wang et al. 2005; He et al. 2011). These two types of adakite may be differentiated using geochemical characteristics (Liu et al. 2010; Sun et al. 2012). Cenozoic adakites formed at 30-9 Ma in the Gangdese belt and are taken as post-collisional intrusions based on their ages relative to the collision. Adakites younger than $\sim 23 \mathrm{Ma}$ are of slab melting origin (Fig. 3) and are associated with porphyry deposits. In contrast, slightly older adakites plot in the field defined by partial melting of continental crust. These adakites are barren and are attributed to foundering of thickened lower crust (Chung et al. 2009). Such transition implies major tectonic changes in the Gangdese. The most straightforward explanation is the commencement of the subduction of the Ninetyeast Ridge.

The ore-forming adakites are distributed near the eastern Himalayan syntaxis. Moreover, 90\% of the $\mathrm{Cu}$ reserves are located in the east end of the belt, along a north-south axis about $100 \mathrm{~km}$ long, next to the eastern Himalayan syntaxis, with the two largest porphyry copper deposits in the belt, the Qulong and Jiama ( $>10$ million tonnes of $\mathrm{Cu}$ metal reserves each) occurring here. These major porphyry copper deposits in the Gangdese belt have much higher $\varepsilon_{\mathrm{Hf}}$, $\varepsilon_{\mathrm{Nd}}$, and oxygen fugacity than other contemporaneous adakitic porphyries in the belt (Fig. 4). Their higher $\varepsilon_{\mathrm{Hf}}$ and $\varepsilon_{\mathrm{Nd}}$ values have been attributed to partial melting of either juvenile crust derived from the mantle (Hou et al. 2009) or relicts of previously subducted Jurassic oceanic crust (Hou et al. 2015) during post-collisional extension in the Tibetan Orogen. However, this is not supported by $\mathrm{Sr} / \mathrm{Y}-\mathrm{La} / \mathrm{Yb}$ data (Fig. 3), which do not show the high $\mathrm{La} / \mathrm{Yb}$ expected for continental adakite. Instead, it may be better explained by slab melting. Continental crust has consistently lower $\mathrm{Cu}$ content than oceanic crust, so slab melts are far more favorable for $\mathrm{Cu}$ deposits than continental crust melts (Sun et al. 2011, 2012).

More importantly, the oxygen fugacities of these adakites are very high, consistent with subduction-related magmas (Ballhaus 1993; Kelley and Cottrell 2009) but much higher than post-collisional magmas. The oxygen fugacity of adakites from Qulong, for example, reached the hematite-magnetite oxygen buffer, which is about four orders of magnitude higher than the fayalite-magnetite- 
Fig. 1 Schematic of the Tibetan Plateau, showing the eastern Himalayan syntaxis, the Gangdese porphyry copper deposits, and subduction direction of the Ninetyeast Ridge. Most of the copper reserves are concentrated in the east end of the belt, close to the eastern Himalayan syntaxis

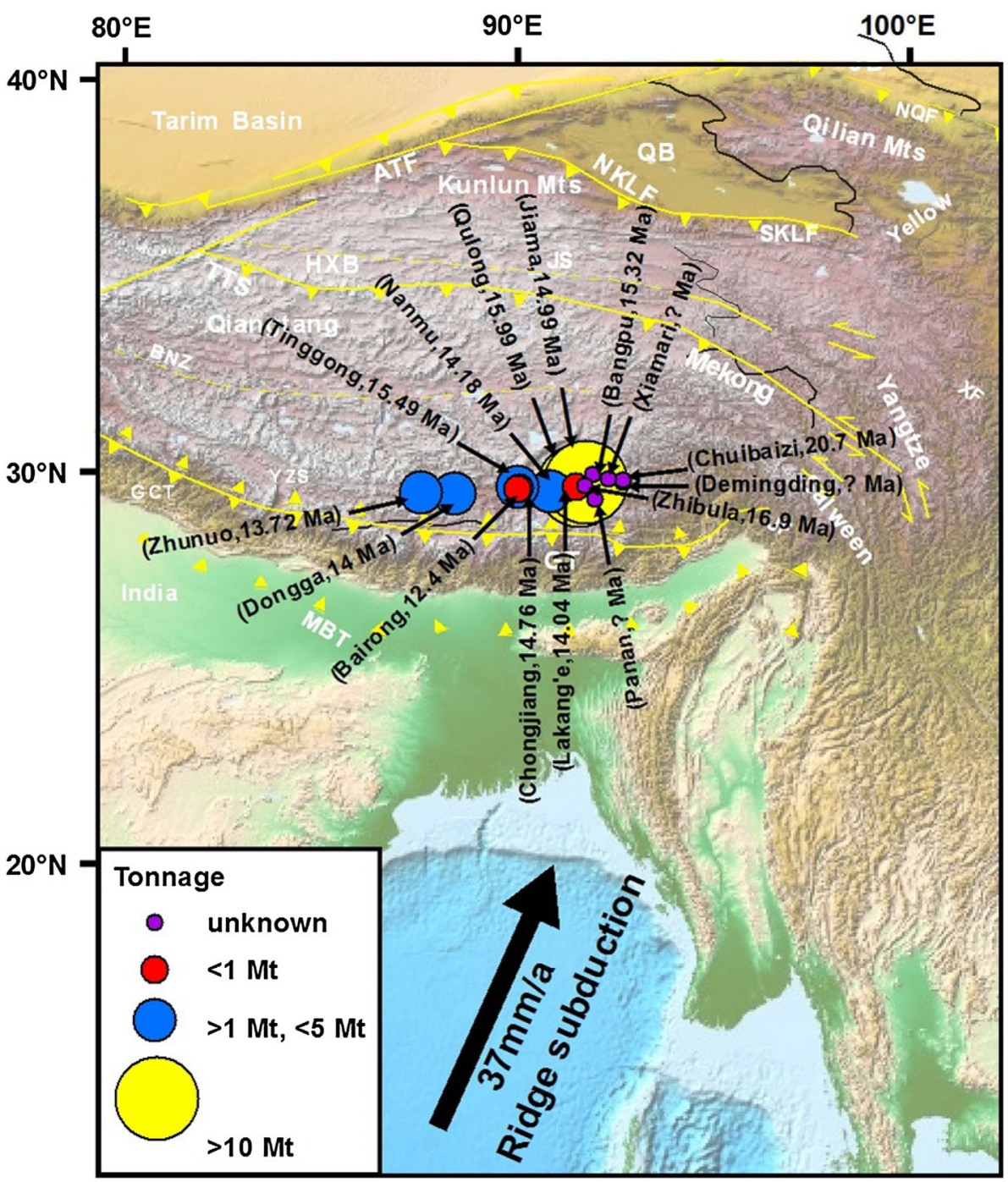

quartz buffer (Sun et al. 2013). Given that sulfate solubility in magma is up to about $1 \%$, whereas that of sulfide is around 1000 parts per million (Jugo 2009), the extremely high sulfur contents in these adakites suggest that the high oxygen fugacity was a primary feature.

Normal mantle has quite uniform oxygen fugacity near the fayalite-magnetite-quartz oxygen buffer, as indicated by mid-ocean ridge basalts and abyssal peridotites (Stagno et al. 2013). Convergent margin magmas have systematically higher oxygen fugacities compared to intraplate settings (Ballhaus 1993; Parkinson and Arculus 1999; Kelley and Cottrell 2009), which is likely due to subduction-released fluids (Sun et al. 2007). Relicts of previously subducted Jurassic oceanic crust (Hou et al. 2015) presumably should have been dehydrated long ago. Partial melting of such oceanic crust cannot form magmas with high oxygen fugacity either. In fact, even mafic arc magmas have oxygen fugacity close to that of mid-ocean ridge basalts (Lee et al. 2010), likely due to the lack of additional fluids.
Moreover, the Gangdese batholith (slightly earlier than the porphyries) was also much more reducing as indicated by tin deposits that predate the porphyries (Hou and Cook 2009). Therefore, it is unlikely that highly oxidizing magmas could form through direct partial melting of mafic lower crust or previously subducted Jurassic oceanic crust in the Miocene in the Gangdese belt.

The coupling between high oxygen fugacity, higher $\varepsilon_{\mathrm{Hf}}$ and $\varepsilon_{\mathrm{Nd}}$, and large $\mathrm{Cu}$ reserves can best be explained by ridge subduction, with the Ninetyeast Ridge as the likely player. At $6000 \mathrm{~km}$ long, $300 \mathrm{~km}$ wide, and several hundred to more than $2000 \mathrm{~m}$ higher than the surrounding Indian Ocean floor, the Ninetyeast Ridge is the largest aseismic ridge in the world. Spatially, the Ninetyeast Ridge is co-terminal with the eastern Himalayan syntaxis of the Tibetan Plateau (Fig. 1), suggesting that a significant fraction of the Ninetyeast Ridge may have already been subducted. The subduction of such a large ridge inevitably results in major deformation of the overriding plate, and 


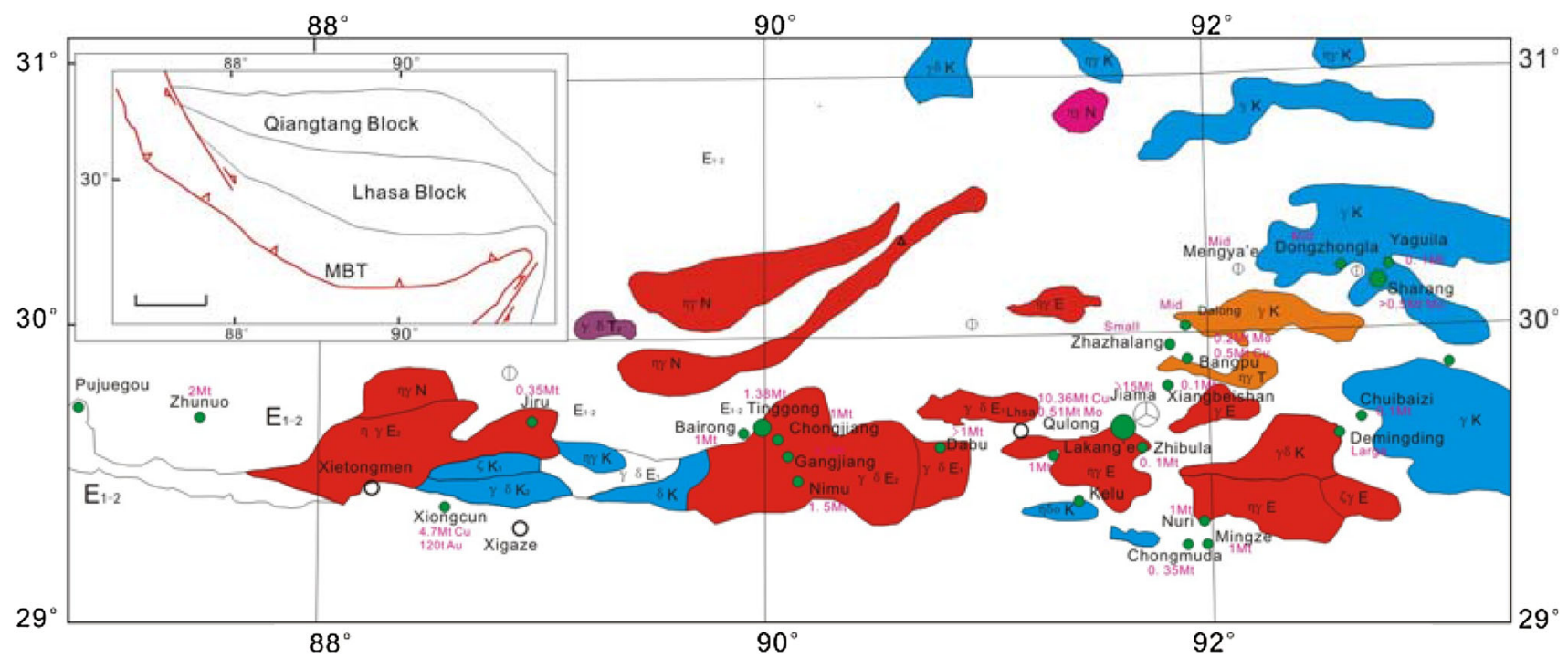

Fig. 2 Distribution of the Gangdese porphyry copper-molybdenum deposits. The Gangdese deposit belt is generally known as roughly east-west extending. About $90 \%$ of the reserves, however, are concentrated along a north-south trending belt in the east end, with two super large deposits, the Jiama and Qulong

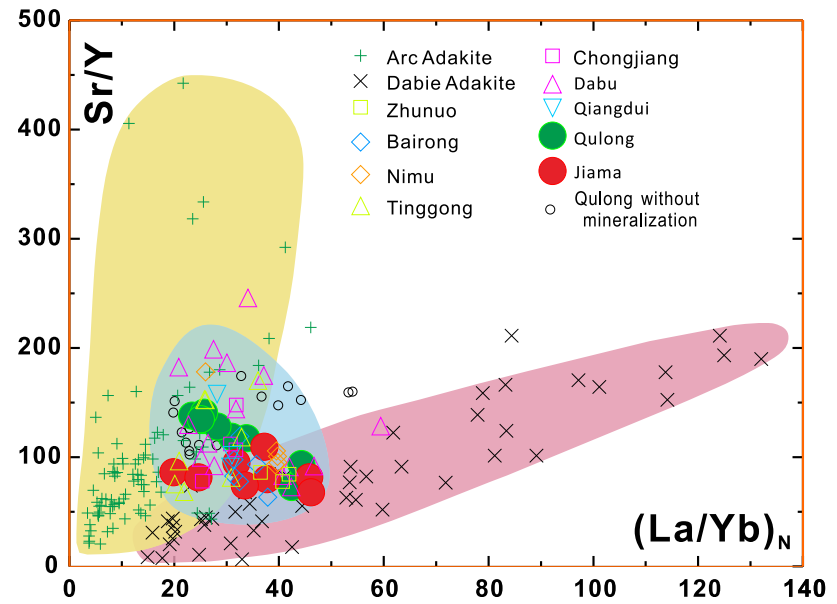

Fig. $3 \mathrm{~A} \mathrm{Sr} / \mathrm{Y}$ versus $\mathrm{La} / \mathrm{Yb}$ diagram for Cenozoic Gangdese adakites associated with the Gangdese porphyry copper deposit. Adakites from circum-Pacific and the Dabie Mountains represent slab and continental crust melts, respectively (Liu et al. 2010; Sun et al. 2012). Adakites older than $23 \mathrm{Ma}$ are barren and plot in the Dabie field. Ore-forming adakites are younger than $23 \mathrm{Ma}$ and show closer affinities to the circum-Pacific adakites, indicating major components from slab melts, essential to copper mineralization (Sun et al. 2011). Some of the adakites from porphyry deposits also plot in the Dabie field likely because of the thick continental crust in the Plateau. The transition is coincident with major tectonic changes in the Tibetan Plateau

correspondingly deeper earthquakes with higher magnitude.

The Ninetyeast Ridge is currently at $\sim 25^{\circ} \mathrm{N}$, moving and subducting northeastward at a speed of $\sim 37 \mathrm{~mm} / \mathrm{year}$ (Subrahmanyam et al. 2008). Based on plate reconstruction, the drifting direction and rate have not changed significantly during the last 23 Ma (van Hinsbergen et al.

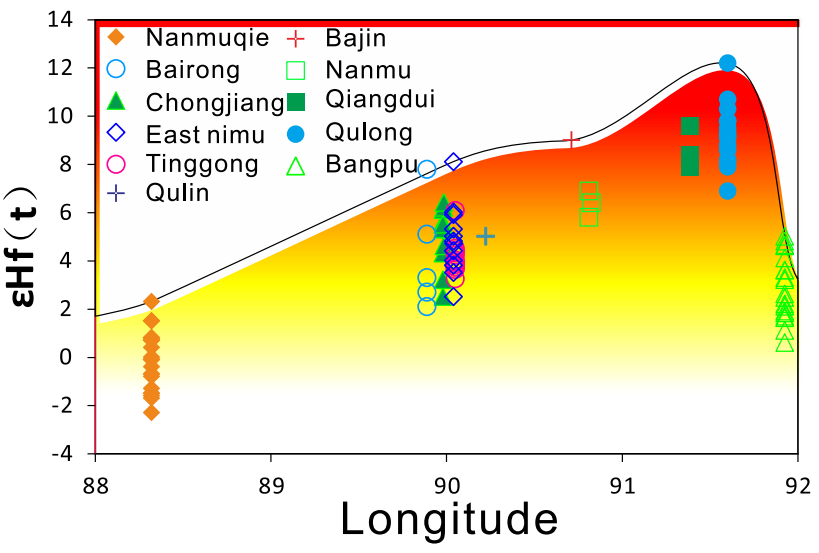

Fig. 4 Variations of $\varepsilon \mathrm{Hf}$ in zircon from the Gangdese porphyry belt from west toeast. The two largest porphyry deposits, the Qulong and Jiama, have the highest $\varepsilon \mathrm{Hf}$, which is consistent with higher proportions of "mantle" derived components

2011). Therefore, the Ninetyeast Ridge has drifted more than $300 \mathrm{~km}$ eastward and $650 \mathrm{~km}$ northward during the last $23 \mathrm{Ma}$, i.e., subduction was likely occurring directly beneath the Gangdese porphyry copper belt at 23 Ma.

Earthquakes deeper than $120 \mathrm{~km}$ in the eastern Tibetan Plateau are concentrated along the northward extension of the Ninetyeast Ridge, pointing towards the eastern Himalayan syntaxis (Fig. 5). Consistently, using seismic ambient noise (Sun et al. 2010), two high-shear-velocity anomalies have been identified near the eastern Himalayan syntaxis: a shallower one in the south at 40-70 km depth and a deeper $(>70 \mathrm{~km})$ one of $>50-\mathrm{km}$ thickness with irregular shape. The deeper high anomaly extends from $22^{\circ} \mathrm{N}$ to $32^{\circ} \mathrm{N}$, several hundred kilometers to the north of 

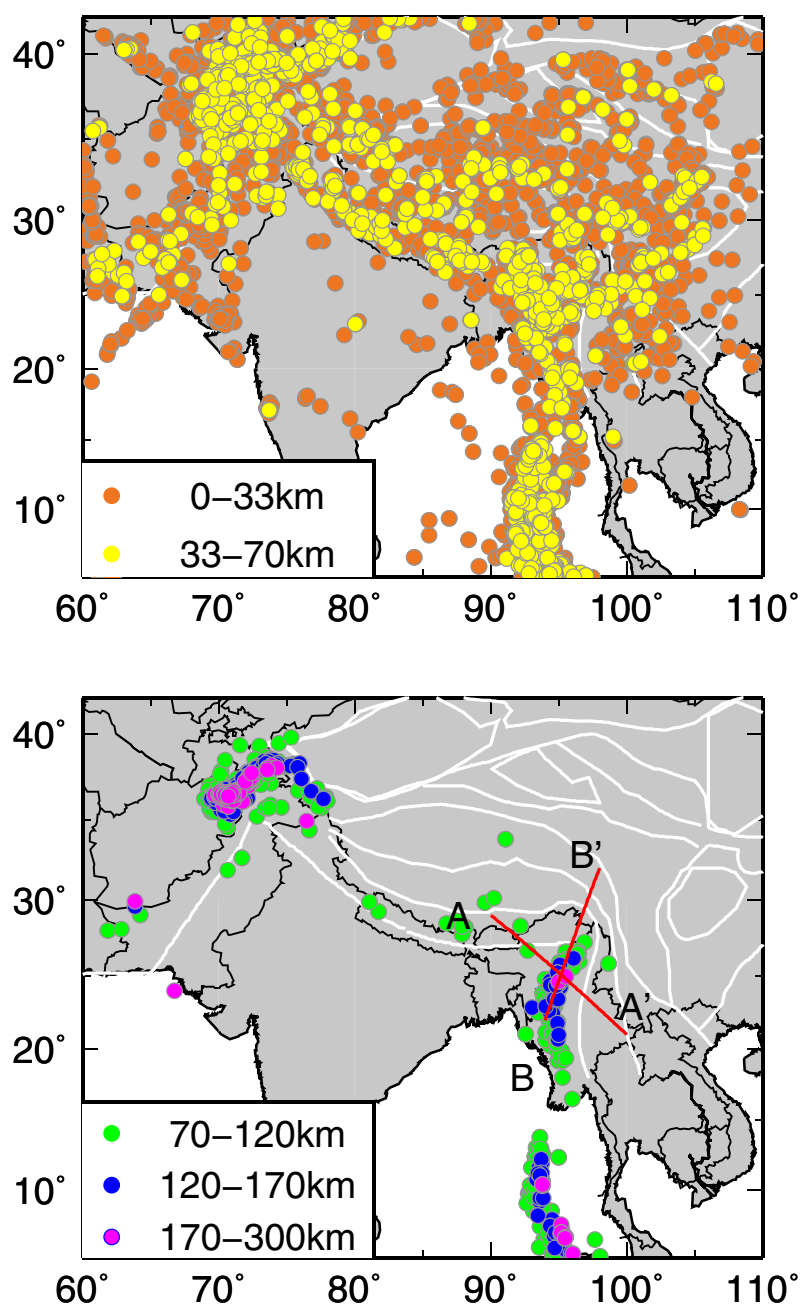

Fig. 5 Earthquake distribution in Tibet and nearby regions. Data are from the National Earthquake Information Center catalog and include all events from 1964 to 2010 of magnitude greater than 4.6. Earthquakes are divided into groups according to depth. Also the positions of the cross sections (red lines) are shown in Fig. 6. White lines are major faults and blocks in China. Earthquakes deeper than $120 \mathrm{~km}$ are concentrated in the eastern and western Himalayan syntaxes. Those in the eastern Himalayan syntaxis are attributed to the subduction of the Ninetyeast Ridge

the Gangdese porphyry deposit belt (Fig. 6). These high velocity anomaly regions are interpreted here as the subducted Ninetyeast Ridge. Similarly, previous studies find high P-wave velocity anomalies: a narrow shallow one, and a wider and deeper one in the Burma subduction, to the south of the eastern Himalayan syntaxis ( $\mathrm{Li}$ et al. 2008). Our results show that the anomalies extend to the Gangdese. These, together with the northeastward drifting direction of the Indian Plate indicate that the Ninetyeast Ridge was, and is still, subducting beneath the eastern Tibetan Plateau.
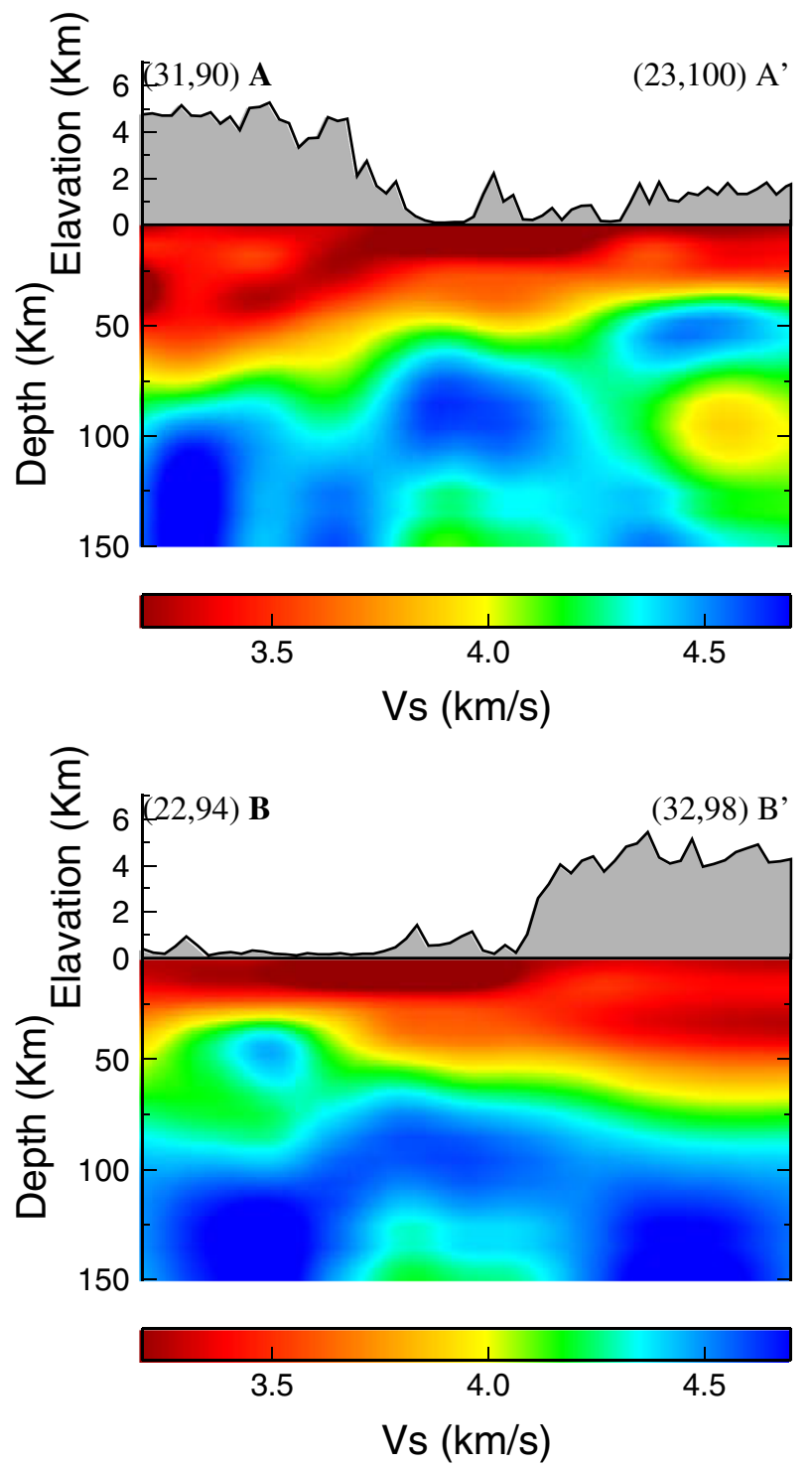

Fig. 6 Cross sections of shear velocity (positions are shown in Fig. 5). Also shown on top is the topography along the eastern Himalayan syntaxis. AA ${ }^{\prime}$ is along great circle from $\left(31^{\circ} \mathrm{N}, 90^{\circ} \mathrm{E}\right)$ to $\left(23^{\circ} \mathrm{N}, 100^{\circ} \mathrm{E}\right) . \mathrm{A} \sim 30-\mathrm{km}$ thick high velocity anomaly region is clearly shown at about $40-70 \mathrm{~km}$ at the eastern end of AA'. Another high velocity region $>50-\mathrm{km}$ thick with an irregular shape extends from $22^{\circ} \mathrm{N}$ to $32^{\circ} \mathrm{N}$ or even further. These anomalies are likely the subducted Ninetyeast Ridge. Note the Gangdese porphyry deposit belt is located at $\sim 29^{\circ} \mathrm{N}$, and the deeper anomaly goes beyond $32^{\circ} \mathrm{N}$

\section{Discussion and conclusion}

The asymmetric distributions of $\mathrm{Cu}$ reserves and chemical characteristics of the Gangdese porphyry belt are partially due to different erosion styles/rates induced by subduction of the Ninetyeast Ridge. Porphyry $\mathrm{Cu}$ deposits formed at paleodepths of $<4 \mathrm{~km}$ (Sillitoe 2010), and are likely controlled by the solubility of ore-bearing fluids in magmas. The widespread preservation of porphyry deposits in 
the Gangdese porphyry belt indicates denudation of $<4 \mathrm{~km}$ since their formation at 23-15 Ma. In contrast, the lack of Miocene porphyry further east is likely due to intensive erosion (i.e., erosion to depths of $>40 \mathrm{~km}$ ) as indicated by the wide exposure of granulite (Zhang et al. 2010).

The oldest ore-forming adakite formed at $\sim 23 \mathrm{Ma}$. Partial melting of subducted oceanic crust occurs at depths $>100 \mathrm{~km}$ and the drifting rate of the Indian Ocean was $\sim 30 \mathrm{~mm} /$ year in the Miocene, so it would take $\sim 3 \mathrm{Ma}$ for the ridge to be subducted deep enough to form adakite, i.e. the initiation of ridge subduction is $\sim 3$ Ma earlier than the oldest adakite. Therefore, the subduction of the Ninetyeast Ridge must have started at $\sim 26 \mathrm{Ma}$, promoting the uplift of the Tibetan Plateau and major consequent changes in tectonic and climatic regimes.

Based on these observations, we propose that initiation of subduction of the Ninetyeast Ridge changed the geometry and rheology of the eastern Tibetan Plateau significantly at $\sim 23$ Ma. Subsequently, subduction of the ridge restrained the asthenosphere and blocked the eastward escape of mantle and continental fragments. Meanwhile, crustal shortening induced by collision was mainly accommodated by uplift, and thus promoted the raising of the Tibetan Plateau. Partial melting of the subducted Ninetyeast Ridge produced adakites with high oxygen fugacity, and high $\mathrm{Cu}$ and sulfur contents - the Gangdese porphyry $\mathrm{Cu}$ deposit belt. Meanwhile, uplift of the Tibetan Plateau triggered the onset of the modern Asian monsoonal system between 22 and $25 \mathrm{Ma}$ (Clift et al. 2008; Licht et al. 2014; Prell and Kutzbach 1992) and east-west crustal extension generated ultrapotassium volcanic rocks at $\sim 23 \mathrm{Ma}$ (Liu et al. 2014).

The Miocene east-west crustal extensions in southern Tibet has previously been interpreted as gravitational collapse resulting from the extreme elevation (Coleman and Hodges 1995; Williams et al. 2001). Remarkably, such extension is associated with the cessation of the southeastward fragmentation, i.e., the Plateau grew high enough, but most of this motion did not extend beyond the plateau. These conclusions strongly support that both the rapid uplift and oroclinal structure of the eastern Himalayan syntaxis are due to the roughly perpendicular subduction of the Ninetyeast Ridge. Such a geometry dramatically changed the boundary conditions in the eastern Tibetan Plateau, which controls the large-scale lateral variations of the tectonic regime within Tibet (Copley et al. 2011), i.e. eastward motion within the Plateau due to gravitational collapse.

Acknowledgements This study was supported by NSFC 91328204 to W.D.S. and Strategic Priority Research Program (B) of the Chinese Academy of Sciences (XDB18020102) to W.D.S. and X.L.S.

\section{References}

Aitchison JC, Ali JR, Davis AM (2007) When and where did India and Asia collide? J Geophys Res. https://doi.org/10.1029/ 2006JB004706

Ballhaus C (1993) Oxidation states of the lithospheric and asthenospheric upper mantle. Contrib Mineral Petrol 114:331-348

Chung SL, Liu DY, Ji JQ, Chu MF, Lee HY, Wen DJ, Lo CH, Lee TY, Qian Q, Zhang Q (2003) Adakites from continental collision zones: melting of thickened lower crust beneath southern Tibet. Geology 31:1021-1024

Chung SL, Chu MF, Ji JQ, O’Reilly SY, Pearson NJ, Liu DY, Lee TY, Lo CH (2009) The nature and timing of crustal thickening in Southern Tibet: Geochemical and zircon Hf isotopic constraints from postcollisional adakites. Tectonophysics 477:36-48

Clift PD, Hodges KV, Heslop D, Hannigan R, Van Long H, Calves G (2008) Correlation of Himalayan exhumation rates and Asian monsoon intensity. Nat Geosci 1:875-880

Coleman M, Hodges K (1995) Evidence for Tibetan Plateau uplift before 14-Myr ago from a new minimum age for east-west extension. Nature 374:49-52

Copley A, Avouac JP, Wernicke BP (2011) Evidence for mechanical coupling and strong Indian lower crust beneath southern Tibet. Nature 472:79-81

Defant MJ, Drummond MS (1990) Derivation of some modern arc magmas by melting of young subducted lithosphere. Nature 347:662-665

Ding L, Spicer RA, Yang J, Xu Q, Cai F, Li S, Lai Q, Wang H, Spicer TEV, Yue Y, Shukla A, Srivastava G, Khan MA, Bera S, Mehrotra R (2017) Quantifying the rise of the Himalaya orogen and implications for the South Asian monsoon. Geology 45:215-218

Gao S, Rudnick RL, Yuan HL, Liu XM, Liu YS, Xu WL, Ling WL, Ayers J, Wang XC, Wang QH (2004) Recycling lower continental crust in the North China craton. Nature 432:892-897

Hall R, Morley CK (2004) Sundaland basins. In: Clift P, Wang P, Kuhnt W, Hayes D (eds) Continent-ocean interactions within east Asian marginal seas. American Geophysical Union, pp 55-85

Harrison TM, Copeland P, Kidd WSF, Yin A (1992) Raising Tibet. Science 255:1663-1670

He YS, Li SG, Hoefs J, Huang F, Liu SA, Hou ZH (2011) Postcollisional granitoids from the Dabie orogen: new evidence for partial melting of a thickened continental crust. Geochim Cosmochim Acta 75:3815-3838

Hou ZQ, Cook NJ (2009) Metallogenesis of the Tibetan collisional orogen: a review and introduction to the special issue. Ore Geol Rev 36:2-24

Hou ZQ, Gao YF, Qu XM, Rui ZY, Mo XX (2004) Origin of adakitic intrusives generated during mid-Miocene east-west extension in southern Tibet. Earth Planet Sci Lett 220:139-155

Hou ZQ, Yang ZM, Qu XM, Meng XJ, Li ZQ, Beaudoin G, Rui ZY, Gao YF, Zaw K (2009) The Miocene Gangdese porphyry copper belt generated during post-collisional extension in the Tibetan Orogen. Ore Geol Rev 36:25-51

Hou ZQ, Yang ZM, Lu YJ, Kemp A, Zheng YC, Li QY, Tang JX, Yang ZS, Duan LF (2015) A genetic linkage between subduction- and collision-related porphyry $\mathrm{Cu}$ deposits in continental collision zones. Geology. https://doi.org/10.1130/G36362.36361

Hu Y-B, Liu J-Q, Ling M-X, Ding W, Liu Y, Zartman RE, Ma X-F, Liu D-Y, Zhang C-C, Sun S-J, Zhang L-P, Wu K, Sun W-D (2015) The formation of Qulong adakites and their relationship with porphyry copper deposit: geochemical constraints. Lithos. https://doi.org/10.1016/j.lithos.2014.1012.1025 
Jugo PJ (2009) Sulfur content at sulfide saturation in oxidized magmas. Geology 37:415-418

Kelley KA, Cottrell E (2009) Water and the oxidation state of subduction zone magmas. Science 325:605-607

Lee CTA, Luffi P, Le Roux V, Dasgupta R, Albarede F, Leeman WP (2010) The redox state of arc mantle using $\mathrm{Zn} / \mathrm{Fe}$ systematics. Nature 468:681-685

Leloup PH, Lacassin R, Tapponnier P, Scharer U, Zhong DL, Liu XH, Zhang LS, Ji SC, Trinh PT (1995) The Ailao Shan-Red River shear zone (Yunnan, China), tertiary transform boundary of Indochina. Tectonophysics 251:3-84

Li C, Van der Hilst RD, Meltzer AS, Engdahl ER (2008) Subduction of the Indian lithosphere beneath the Tibetan Plateau and Burma. Earth Planet Sci Lett 274:157-168

Licht A, van Cappelle M, Abels HA, Ladant JB, Trabucho-Alexandre J, France-Lanord C, Donnadieu Y, Vandenberghe J, Rigaudier T, Lecuyer C, Terry D, Adriaens R, Boura A, Guo Z, Soe AN, Quade J, Dupont-Nivet G, Jaeger JJ (2014) Asian monsoons in a late Eocene greenhouse world. Nature 513:501

Liu SA, Li SG, He Y, Huang F (2010) Geochemical contrasts between early Cretaceous ore-bearing and ore-barren high-Mg adakites in central-eastern China: implications for petrogenesis and $\mathrm{Cu}-\mathrm{Au}$ mineralization. Geochim Cosmochim Acta 74:7160-7178

Liu D, Zhao ZD, Zhu DC, Niu YL, DePaolo DJ, Harrison TM, Mo XX, Dong GC, Zhou S, Sun CG, Zhang ZC, Liu JL (2014) Postcollisional potassic and ultrapotassic rocks in southern Tibet: mantle and crustal origins in response to India-Asia collision and convergence. Geochim Cosmochim Acta 143:207-231

Maruyama S, Hasegawa A, Santosh M, Kogiso T, Omori S, Nakamura H, Kawai K, Zhao D (2009) The dynamics of big mantle wedge, magma factory, and metamorphic-metasomatic factory in subduction zones. Gondwana Res 16:414-430

Meng J, Wang CS, Zhao XX, Coe R, Li YL, Finn D (2012) India-Asia collision was at 24 degrees $\mathrm{N}$ and $50 \mathrm{Ma}$ : palaeomagnetic proof from southernmost Asia. Sci Rep-Uk 2:925

Parkinson IJ, Arculus RJ (1999) The redox state of subduction zones: insights from arc-peridotites. Chem Geol 160:409-423

Prell WL, Kutzbach JE (1992) Sensitivity of the Indian monsoon to forcing parameters and implications for its evolution. Nature 360:647-652

Richards JP (2009) Postsubduction porphyry $\mathrm{Cu}-\mathrm{Au}$ and epithermal $\mathrm{Au}$ deposits: products of remelting of subduction-modified lithosphere. Geology 37:247-250

Royden LH, Burchfiel BC, van der Hilst RD (2008) The geological evolution of the Tibetan plateau. Science 321:1054-1058

Sibuet JC, Hsu SK, Debayle E (2004) Geodynamic context of the Taiwan Orogen. In: Clift P, Kuhnt W, Wang P, Hayes H (eds) Continent-ocean interactions within east Asian marginal seas. American Geophysical Union, pp 127-158

Sillitoe RH (2010) Porphyry copper systems. Econ Geol 105:3-41

Spicer RA, Harris NBW, Widdowson M, Herman AB, Guo SX, Valdes PJ, Wolfe JA, Kelley SP (2003) Constant elevation of southern Tibet over the past 15 million years. Nature 421:622-624

Stagno V, Ojwang DO, McCammon CA, Frost DJ (2013) The oxidation state of the mantle and the extraction of carbon from Earth's interior. Nature 493:84-88
Subrahmanyam C, Gireesh R, Chand S, Raju KAK, Rao DG (2008) Geophysical characteristics of the Ninetyeast Ridge-Andaman island arc/trench convergent zone. Earth Planet Sci Lett 266:29-45

Sun XM, Tang Q, Sun WD, Xu L, Zhai W, Liang JL, Liang YH, Shen K, Zhang ZM, Zhou B, Wang FY (2007) Monazite, iron oxide and barite exsolutions in apatite aggregates from CCSD drillhole eclogites and their geological implications. Geochim Cosmochim Acta 71:2896-2905

Sun XL, Song XD, Zheng SH, Ritzwoller MH (2010) Three dimensional shear wave velocity structure of the crust and upper mantle beneath China from ambient noise surface wave tomography. Earthq Sci 23:449-463

Sun WD, Zhang H, Ling MX, Ding X, Chung SL, Zhou JB, Yang XY, Fan WM (2011) The genetic association of adakites and $\mathrm{Cu}-\mathrm{Au}$ ore deposits. Int Geol Rev 53:691-703

Sun WD, Ling MX, Chung SL, Ding X, Yang XY, Liang HY, Fan WM, Goldfarb R, Yin QZ (2012) Geochemical constraints on adakites of different origins and copper mineralization. J Geol 120:105-120

Sun WD, Liang HY, Ling MX, Zhan MZ, Ding X, Zhang H, Yang XY, Li YL, Ireland T, Wei QR, Fan WM (2013) The link between reduced porphyry copper deposits and oxidized magmas. Geochim Cosmochim Acta 103:263-275

Sun WD, Huang RF, Li H, Hu YB, Zhang CC, Sun SJ, Zhang LP, Ding X, Li CY, Zartman RE, Ling MX (2015) Porphyry deposits and oxidized magmas. Ore Geol Rev 65:97-131

Tapponnier P, Peltzer G, Ledain AY, Armijo R, Cobbold P (1982) Propagating extrusion tectonics in Asia-New insights from simple experiments with plasticine. Geology 10:611-616

Tapponnier P, Xu ZQ, Roger F, Meyer B, Arnaud N, Wittlinger G, Yang JS (2001) Geology-oblique stepwise rise and growth of the Tibet Plateau. Science 294:1671-1677

Taylor B, Hayes DE (1980) The tectonic evolution of the South China Basin. In: Hayes DE (ed) The tectonic and geologic evolution of Southeast Asian seas and islands, part 1. American Geophysical Union, Geophysical Monograph, Washington, pp 89-104

van Hinsbergen DJJ, Steinberger B, Doubrovine PV, Gassmoller R (2011) Acceleration and deceleration of India-Asia convergence since the Cretaceous: roles of mantle plumes and continental collision. J Geophys Res. https://doi.org/10.1029/2010JB008051

Wang Q, McDermott F, Xu JF, Bellon H, Zhu YT (2005) Cenozoic K-rich adakitic volcanic rocks in the Hohxil area, northern Tibet: lower-crustal melting in an intracontinental setting. Geology 33:465-468

Williams H, Turner S, Kelley S, Harris N (2001) Age and composition of dikes in Southern Tibet: new constraints on the timing of east-west extension and its relationship to postcollisional volcanism. Geology 29:339-342

Xiao B, Qin KZ, Li GM, Li JX, Xia DX, Chen L, Zhao JX (2012) Highly oxidized magma and fluid evolution of Miocene Qulong giant porphyry Cu-Mo deposit, southern Tibet, China. Resour Geol. https://doi.org/10.1111/j.1751-3928.2011.00177.x

Zhang ZM, Zhao GC, Santosh M, Wang JL, Dong X, Liou JG (2010) Two stages of granulite facies metamorphism in the eastern Himalayan syntaxis, south Tibet: petrology, zircon geochronology and implications for the subduction of Neo-Tethys and the Indian continent beneath Asia. J Metamorph Geol 28:719-733 